\title{
What is the clinical evidence of Bulk Fill resins performance of in primary and permanent teeth? a systematic review and meta-analysis
}

Qual é a evidencia clínica do desempenho das resinas Bullk Fill em dentes decíduos e permanentes? uma revisão sistemática e meta-análise

¿Cuál es la evidencia clinica del rendimiento de las resinas Bulk Fill en los dientes primarios y permanentes? una revisión sistemática y un metanálisis

\author{
Ana Carolina Soares Diniz \\ ORCID: https://orcid.org/0000-0002-0609-1906 \\ Universidade Federal do Maranhão, Brazil \\ E-mail: carol_diniz5@hotmail.com \\ Vinicius Souza Correia \\ ORCID: https://orcid.org/0000-0002-7811-3748 \\ Universidade Federal do Maranhão, Brazil \\ E-mail: viniciusousa_@hotmail.com \\ Meire Coelho Ferreira \\ ORCID: https://orcid.org/0000-0001-7116-1547 \\ Universidade Ceuma, Brazil \\ E-mail: meirecofe@hotmail.br \\ Leily Macedo Firoozmand \\ ORCID: https://orcid.org/0000-0002-8634-188X \\ Universidade Federal do Maranhão, Brazil \\ E-mail: leilyfiroozmand@hotmail.com
}

\begin{abstract}
With the increasing acceptance of the clinical use of bulk-fill resins, it is necessary to investigate the in vivo performance of these restorative materials. In this perspective, this systematic review to evaluate the clinical performance of Bulk-fill resins in restorations of vital, primary and permanent posterior teeth. PubMed, Cochrane, Scopus, LILACS, BBO and Capes publications search base were searched without restriction regarding the year of publication or language of the article. The inclusion criteria were clinical trials that evaluated the efficacy of resins composed of bulk-fill compared to the incremental technique. For the selection of articles and data extraction, two calibrated evaluators evaluated abstracts and complete articles. A total of 1443 abstracts were identified, of which 14 articles were included in the review. Of these, 01 was classified with a high level of evidence; 08 were moderate and 05 with a low level of evidence. The studies presented an average follow-up of the restorations of 35.1 months. A large part of the studies (75\%) demonstrated that the occurrence of postoperative sensitivity. The high failure rate was more prevalent in class II restorations. The marginal adaptation/color change was material dependent and the occurrence of secondary caries in bulk-fill resin restorations was not significant concerning conventional resins in most studies. In the short term, the satisfactory clinical performance of bulk-fill resins used in primary and permanent restorations, with clinical outcomes and results equivalent to conventional composite resins were observed.
\end{abstract}

Keywords: Dental restoration, permanent; Dentin sensitivity; Dental caries; Bulk fill.

\section{Resumo}

Com a crescente aceitação do uso clínico de resinas bulk-fill, é necessário investigar o desempenho in vivo desses materiais restauradores. Nesta perspectiva, esta revisão sistemática avaliou o desempenho clínico de resinas Bulk-fill em restaurações de dentes posteriores vitais, decíduos e permanentes. As bases de buscas das publicações PubMed, Cochrane, Scopus, LILACS, BBO e Capes foram pesquisadas sem restrições quanto ao ano de publicação ou idioma do artigo. Os critérios de inclusão foram ensaios clínicos que avaliaram a eficácia de resinas compostas de bulk-fill em comparação à técnica incremental. Para a seleção dos artigos e extração dos dados, dois avaliadores calibrados avaliaram resumos e artigos completos. Um total de 1443 resumos foram identificados, dos quais 14 artigos foram incluídos na revisão. Destes, 01 foi classificado com alto nível de evidência; 08 eram moderados e 05 com baixo nível de evidência. Os estudos apresentaram um acompanhamento médio das restaurações de 35,1 meses. Grande parte dos estudos $(75 \%)$ demonstrou a ocorrência de sensibilidade pós-operatória. A alta taxa de falha foi mais prevalente em restaurações de classe II. A adaptação marginal / mudança de cor foi dependente do material e a ocorrência de cárie secundária em restaurações de resina bulk-fill não foi significativa em relação às resinas convencionais na maioria dos 
estudos. Em curto prazo, observou-se o desempenho clínico satisfatório das resinas bulk-fill utilizadas em restaurações primárias e permanentes, com desfechos clínicos e resultados equivalentes às resinas compostas convencionais.

Palavras-chave: Restauração dentária permanente; Sensibilidade da dentina; Cárie dentária; Bulk fill.

\section{Resumen}

Con la creciente aceptación del uso clínico de resinas bulk-fill, es necesario investigar el desempeño in vivo de estos materiales de restauración. En esta perspectiva, esta revisión sistemática evaluó el desempeño clínico de las resinas Bulk fill en restauraciones de dientes posteriores vitales, deciduos y permanentes. Se realizaron búsquedas en las bases de búsqueda de las publicaciones PubMed, Cochrane, Scopus, LILACS, BBO y Capes sin restricciones en cuanto al año de publicación o idioma del artículo. Los criterios de inclusión fueron ensayos clínicos que evaluaran la eficacia de resinas compuestas bulk-fill en comparación con la técnica incremental. Para la selección de artículos y extracción de datos, dos evaluadores calibrados evaluaron resúmenes y artículos completos. Se identificaron un total de 1443 resúmenes, de los cuales 14 artículos se incluyeron en la revisión. De estos, 01 se clasificó como de alto nivel de evidencia; 08 fueron moderados y 05 con bajo nivel de evidencia. Los estudios mostraron un seguimiento medio de las restauraciones de 35,1 meses. Una gran parte de los estudios (75\%) demostró la aparición de sensibilidad posoperatoria. La alta tasa de fallas fue más prevalente en las restauraciones de clase II. La adaptación marginal / cambio de color dependía del material y la aparición de caries secundaria en las restauraciones de resina de relleno masivo no fue significativa en comparación con las resinas convencionales en la mayoría de los estudios. A corto plazo, se observó el desempeño clínico satisfactorio de las resinas bulk-fill utilizadas en restauraciones primarias y permanentes, con resultados clínicos y resultados equivalentes a las resinas compuestas convencionales.

Palabras clave: Restauración dental permanente; Sensibilidad de la dentina; Caries dental; Bulk fill.

\section{Introduction}

The decrease in tension and polymerization shrinkage stresses of composite resin is a great desired challenge, contributing to a good clinical performance of direct restorations (Al Sunbul et al., 2016; Gonçalves et al., 2008; Stansbury et al., 2005). Thus, materials have been investigated, such as bulk-fill resins, which besides having a simplified technique, are promising for restorations in extensive cavities of posterior teeth(Alkurdi \& Abboud, 2016; van Dijken \& Pallesen, 2014, 2016). In vitro studies have demonstrated that bulk-fill resins present microhardness values (Fronza et al., 2015), polymerization shrinkage(Schneider et al., 2010), conversion degree (Czasch \& Ilie, 2013; Fronza et al., 2015) and marginal sealing(Orlowski et al., 2015) equivalent to the conventional resins inserted by the incremental technique. Bulk-fill resins present as an advantage the reduction of clinical time, since they may be inserted and photopolymerized in large increments (45mm) (Olegário et al., 2017; Roggendorf et al., 2011).

The evaluation of the polymerization shrinkage of composite resin restorations is largely related to marginal adaptation and sealing within the cavity(Schneider et al., 2010). Clinical assessments have shown that an inappropriate marginal adaptation of the resin may lead to gaps formation and consequently trigger postoperative sensitivity(Reis et al., 2015), marginal discoloration(Heintze et al., 2009) and/or secondary caries (Dennison \& Sarrett, 2012). Besides, high polymerization tension may lead to cusp deflection, increasing the likelihood of dental hypersensitivity or cracks/fractures formation in the cavity walls (Ferracane \& Hilton, 2016).

It is known that the results of in vitro studies cannot be extrapolated to the definition of clinical behavior(Heintze et al., 2015). Once verified satisfactory laboratory results with the use of bulk-fill resins, the clinical performance and longevity of these treatments must be confirmed through randomized clinical trials (Alkurdi \& Abboud, 2016; van Dijken \& Pallesen, 2014, 2016). Through clinical evaluation of direct restorations, it is possible to evaluate parameters such as color stability, anatomical form, marginal adaptation/discoloration, postoperative sensitivity, and surface roughness, besides allowing the early diagnosis of secondary caries lesions (Alkurdi \& Abboud, 2016; van Dijken \& Pallesen, 2014, 2016, 2017).

With the performance of randomized clinical trials (RCT) and systematic reviews of RCTs, more reliable evidence on the effects of interventions may be achieved(Higgins et al., 2011). A systematic analysis of the efficacy and longevity of bulkfill resins restorations in vital posterior teeth allows the acquisition of greater scientific evidence on the clinical performance of 
these composite resins. Based on the investigations, it is possible to identify the operative steps and identify the clinical conditions capable of resulting in greater success in the restorative treatment.

Thus, the present study aimed to conduct a systematic review and meta-analysis to indicate more consistent evidence on the clinical efficacy of bulk-fill resins in restorations of primary and permanent posterior teeth. For this systematic review, the PICO question was applied: Population (posterior teeth with restorative need); Intervention (restorations class I and II with bulk-fill resins on posterior teeth); Comparison (restorations class I and II with composite conventional resins on posterior teeth); and Outcomes (postoperative sensibility, discoloration and marginal adaptation, secondary caries, anatomical form, texture and surface roughness).

\section{Methodology}

The systematic review was conducted according to the guidelines of the Preferred Reporting Items for Systematic Reviews and Meta-Analyses (PRISMA)(Moher et al., 2009) and submitted to PROSPERO (CRD 42017064063).

\section{Eligibility Criteria}

In this systematic review were included randomized and non-randomized clinical trials, without considering a minimum follow-up time, which was in agreement with the PICO question. The exclusion criteria were: cohort studies; casecontrol studies; case reports or case series; letters to the editor; abstracts and randomized and non-randomized clinical trials evaluating anterior tooth restorations, early-stage clinical studies, in vitro studies; dissertations and theses that did not generate a published article.

\section{Information sources and search strategy}

The electronic searches were performed on MEDLINE via PubMed (http://www.ncbi.nlm.nih.gov/pubmed), Brazilian Library in Dentistry (BBO) (http://bvsalud.org/), Latin American and Caribbean Health Sciences Literature database (LILACS) (http://lilacs.bvsalud.org/), Capes publications (http://www.periodicos.capes.gov.br/), Scopus (https://www.scopus.com/) and Cochrane Library (http://www.cochranelibrary.com/). Initially, the strategic keywords were selected to encompass all the articles that covered the context of the systematic review. Then, a keyword matching sequence was performed for the searches, where the combinations varied according to the search platform (Table 1). 
Research, Society and Development, v. 10, n. 10, e552101018981, 2021

(CC BY 4.0) | ISSN 2525-3409 | DOI: http://dx.doi.org/10.33448/rsd-v10i10.18981

Table 1. Electronic database and search strategy.

\begin{tabular}{|c|c|c|c|c|c|c|}
\hline Key Words (Mesh e Entry Terms) & PubMed & BBO e Lilacs & $\begin{array}{c}\text { Cochrane } \\
\text { Library }\end{array}$ & Scopus & Periódicos Capes & SIGLE \\
\hline $\begin{array}{l}\text { Bulk fill; Bulk fill composite; Bulk fill resin; Bulk fill composites; Bulk fill resin } \\
\text { composite; Resin Bulk fill; Resins Bulk fill; Bulk fill flow; Composite Bulk fill; Bulk } \\
\text { fill posterior [1] }\end{array}$ & $\begin{array}{l}\text { [1] AND [2] AND [3] } \\
\text { AND [5] AND [6] }\end{array}$ & [1] & \#Bulk fill & \#Bulk fill AND \#Clinical & $\begin{array}{l}\text { [Bulk fill] AND } \\
\text { [Clinical] }\end{array}$ & $\begin{array}{l}\text { (Odontologie) AND } \\
\text { "bulk fill" }\end{array}$ \\
\hline $\begin{array}{l}\text { Dental Restoration, Permanent; Restorations, Permanent Dental; Permanent Dental } \\
\text { Restorations; Restoration, Permanent Dental; Dental Restorations, Permanent; } \\
\text { Permanent Dental Restoration; Dental Permanent Fillings; Fillings, Permanent Dental; } \\
\text { Permanent Dental Fillings; Permanent Fillings, Dental; Permanent Filling, Dental; } \\
\text { Dental Filling, Permanent; Dental Permanent Filling; Filling, Dental Permanent; } \\
\text { Filling, Permanent Denta;; Permanent Dental Filling; Fillings, Dental Permanent; } \\
\text { Dental Fillings, Permanent [2] }\end{array}$ & $\begin{array}{l}\text { [1] AND [2] AND [3] } \\
\text { AND [4] AND [6] }\end{array}$ & [1] AND [6] & & $\begin{array}{l}\text { [1] AND [2] AND [3] } \\
\text { AND [4] AND [7] }\end{array}$ & & $\begin{array}{l}\text { "Bulk fill" AND } \\
\text { "clinical" }\end{array}$ \\
\hline Composite resins; resins, composite [3] & $\begin{array}{l}\text { [1] AND [2] AND [3] } \\
\text { AND [7] }\end{array}$ & $\begin{array}{l}\text { [1] AND [2] AND [3] } \\
\text { AND [6] }\end{array}$ & & [1] AND [7] & & \\
\hline $\begin{array}{l}\text { Dentin Sensitivity; Dentin Sensitivities; Sensitivities, Dentin; Sensitivity, Dentin; } \\
\text { Dentine Hypersensitivity; Dentine Hypersensitivities; Hypersensitivities, Dentine; } \\
\text { Hypersensitivity, Dentine; Dentine Sensitivity; Dentine Sensitivities; Sensitivities, } \\
\text { Dentine; Sensitivity, Dentine; Tooth Sensitivity; Sensitivities, Tooth; Sensitivity, } \\
\text { Tooth; Tooth Sensitivities; Dentin Hypersensitivity; Dentin Hypersensitivities; } \\
\text { Hypersensitivities, Dentin; Hypersensitivity, Dentin [4] }\end{array}$ & $\begin{array}{l}\text { [1] AND [2] AND [3] } \\
\text { AND [7] AND [8] }\end{array}$ & $\begin{array}{l}\text { [1] AND [2] AND [3] } \\
\text { AND [4] AND [6] }\end{array}$ & & $\begin{array}{l}\text { [1] AND [2] AND [3] } \\
\text { AND [5] AND [7] }\end{array}$ & & \\
\hline Dental Leakage; Leakages, Dental; Dental Leakages; Leakage, Dental [5] & $\begin{array}{c}\text { [1] AND [2] AND [3] } \\
\text { AND [6] }\end{array}$ & & & $\begin{array}{l}\text { [1] AND [2] AND [3] } \\
\text { AND [7] }\end{array}$ & & \\
\hline Clinical [6] & $\begin{array}{l}\text { [1] AND [2] AND [3] } \\
\text { AND [5] AND [6] }\end{array}$ & & & $\begin{array}{l}\text { [1] AND [2] AND [3] } \\
\text { AND [8] }\end{array}$ & & \\
\hline Patients; Patient; Clients; Client [7] & $\begin{array}{c}\text { [1] AND [2] AND [3] } \\
\text { AND [6] AND [7] AND } \\
\text { [9] }\end{array}$ & & & $\begin{array}{c}\text { [1] AND [2] AND [3] } \\
\text { AND [5] AND [7] }\end{array}$ & & \\
\hline Child; Children [8] & $\begin{array}{l}\text { [1] AND [2] AND [3] } \\
\text { AND [6] AND [7] }\end{array}$ & & & & & \\
\hline Adult; Adults [9] & $\begin{array}{l}\text { [1] AND [2] AND [3] } \\
\text { AND [6] AND [6] }\end{array}$ & & & & & \\
\hline
\end{tabular}

Source: Authors. 


\section{Results}

A total of 1436 articles were identified in the detailed searches. And through additional searches, 7 articles were found. With the removal of duplicate articles, a total of 937 articles remained (Figure 1). After the reading of the titles and abstracts, 18 articles were pre-selected. After the complete reading of the articles, 14 articles were included in the systematic review. The excluded studies were due to the following reasons: 01 article (Olegário et al., 2017) it was a clinical study in the early phase/l and the treatment application had not yet begun; 01 study (Karaman et al., 2016) was performed only with endodontically treated teeth, being excluded because it did not allow the evaluation of the postoperative sensitivity criterion; 01 study did not approach bulk-fill resins (Casagrande et al., 2013); finally 01 study (Kurdi \& Abboud, 2016) was excluded because it is the same study published in two different journals. In this case, the paper with the greatest impact was selected (Alkurdi \& Abboud, 2016). The final selection consisted of 14 articles that were included in the systematic review. For the quantitative evaluation, only 12 studies were included, 02 studies were excluded (Costa et al., 2017; Hickey et al., 2016) due to their short follow-up.

Figure 1. Flow diagram of identification and selection of studies.

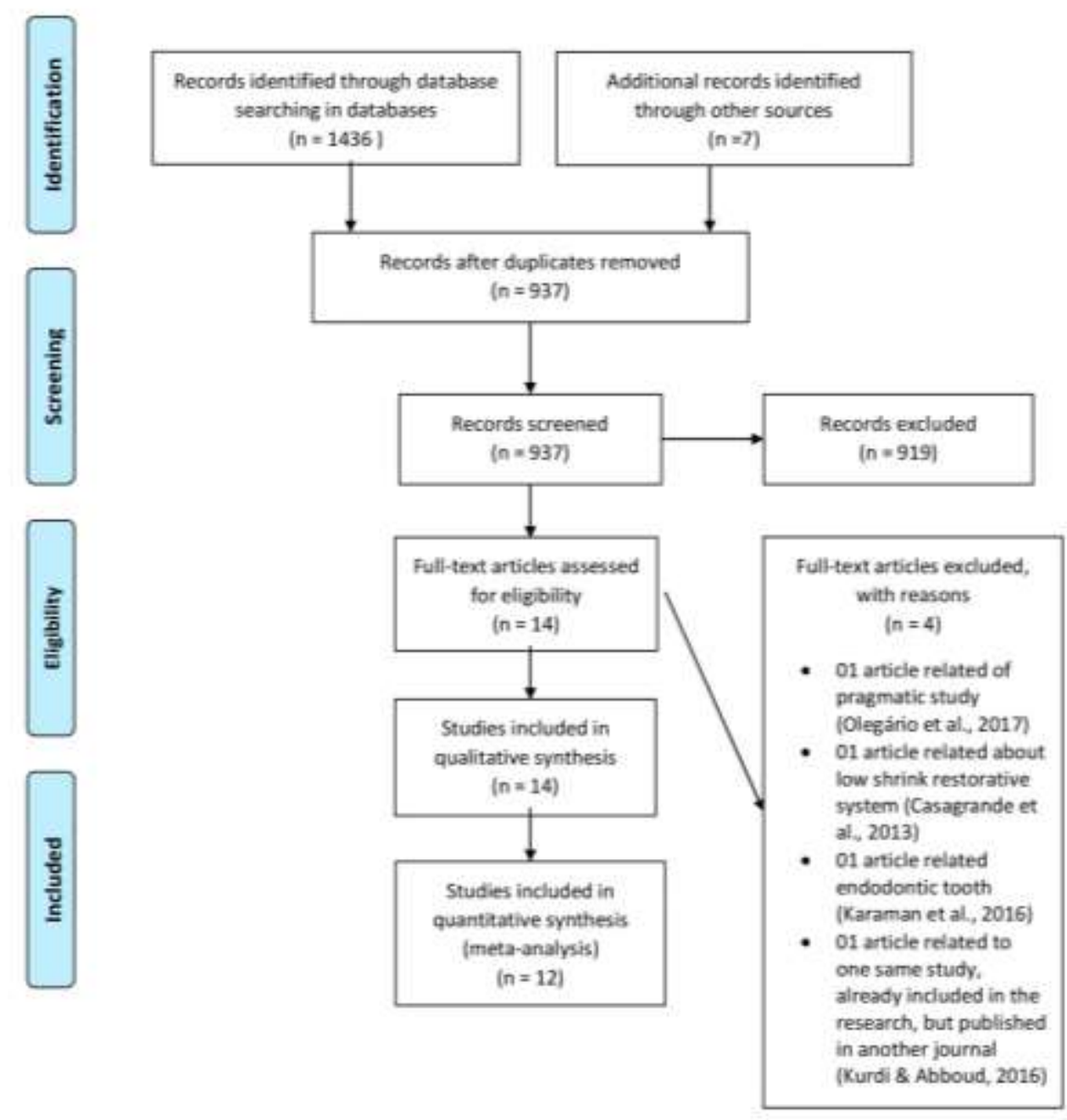

Source: Authors. 


\section{Characteristics of the included articles}

Among the studies included in this review, 04 studies (Arhun et al., 2010; Atabek et al., 2017; Bayraktar et al., 2017; Çolak et al., 2017) did not describe the sample calculation. The number of restorations performed in these studies ranged from 60 to 236. The method of assessing the clinical outcomes for the majority (85.7\%) of the studies followed the modified USPHS criteria, with only one study(Hickey et al., 2016) having applied a LIKERT scale, and other (Costa et al., 2017) using the World Dental Federation criteria and SQUACE criterion.

No previous calibration was performed for outcome assessment in the studies by Arhun et al.(Arhun et al., 2010); Hickey et al.(Hickey et al., 2016); Alkurdi and Abboud(Alkurdi \& Abboud, 2016), Oter et al.(Oter et al., 2018) in these studies the evaluators were not masked for outcome assessment either, as in the study by Bayraktar et al.(Bayraktar et al., 2017) the evaluators also were not masked.

Among all the restorations included in the evaluated studies, most failed due to the occurrence of caries, composite resin fracture, marginal discoloration, among other causes over time (Table 2).

According to the results obtained; only one clinical trial involving the evaluation of bulk-fill resin in primary teeth was found; (Oter et al., 2018). Regarding the severe postoperative sensitivity, only the study by Alkurdi and Abboud (Alkurdi \& Abboud, 2016) demonstrated the need to exchange the restoration in the bulk-fill group.

The highest failure rate occurred in class II restorations, with no significant difference between conventional and bulk-fill resins (Costa et al., 2017; van Dijken \& Pallesen, 2015, 2016, 2017). These failures in Class II restorations occurred on average with 2.5 years after their confection and had several reasons, such as: tooth fracture, caries occurrence or fracture of the composite resin (Arhun et al., 2010; van Dijken \& Pallesen, 2015, 2016, 2017).

After 6 years of evaluation, there was a significant color change when compared to the baseline, such as bulk-fill, as conventional resins (van Dijken \& Pallesen, 2017). 
Research, Society and Development, v. 10, n. 10, e552101018981, 2021

(CC BY 4.0) | ISSN 2525-3409 | DOI: http://dx.doi.org/10.33448/rsd-v10i10.18981

Table 2. Qualitative summary of restoration failures.

\begin{tabular}{|c|c|c|c|c|c|}
\hline \multirow{2}{*}{$\begin{array}{c}\text { Identification } \\
\text { of studies }\end{array}$} & \multirow{2}{*}{ Author, year } & \multicolumn{2}{|c|}{ Conventional resin composite } & \multicolumn{2}{|l|}{ Bulk-fill resin composite } \\
\hline & & Failure number & Total evaluated samples & Failure number & Total evaluated samples \\
\hline & \multicolumn{5}{|c|}{6 months } \\
\hline 1 & Arhun et al., 2010 & - Grandio: 0 & 41 & - Quixfil: 0 & 41 \\
\hline 2 & Bayraktar et al., 2016 & - Clearfil Photo Posterior: 0 & 46 & $\begin{array}{l}\text { - Filtek Bulk-Fill Flowable Restorative + Filtek P60: } \\
\text { Post-operative sensitivity: } 1 \\
\text { - Tetric EvoCeram Bulk Fill: } 0 \\
\text { - SonicFill: } 0\end{array}$ & $\begin{array}{l}46 \\
46 \\
46 \\
\end{array}$ \\
\hline 3 & Çolak et al., 2017 & $\begin{array}{l}\text { - Tetric EvoCeram: } \\
\text { Marginal discoloration: } 1 \\
\end{array}$ & 35 & -Tetric EvoCeram Bulk Fill: 0 & 35 \\
\hline 4 & Atabek et al, 2017 & - Herculite: 0 & 30 & - SonicFill: 0 & 30 \\
\hline 5 & Yazici et al., 2017 & - Filtek Ultimate: 0 & 52 & - Tetric EvoCeram Bulk Fill: 0 & 52 \\
\hline \multirow[t]{2}{*}{6} & Oter et al., 2018 & - Filtek Z250: 0 & 63 & $\begin{array}{l}\text { - Filtek Bulk-Fill Restorative: } \\
\text { Fracture of material and enamel loss: } 1\end{array}$ & 63 \\
\hline & \multicolumn{5}{|c|}{12 months } \\
\hline 1 & Arhun et al., 2010 & - Grandio, Voco: 0 & 41 & $\begin{array}{l}\text { - Quixfil, Dentsply: } \\
\text { Secondary caries: } 2 \\
\end{array}$ & 41 \\
\hline 2 & Bayraktar et al., 2016 & $\begin{array}{l}\text {-Clearfil Photo Posterior: } \\
\text { Secondary caries: } 1\end{array}$ & 43 & $\begin{array}{l}\text {-Filtek Bulk-Fill Flowable Restorative + Filtek P60: } \\
\text { Secondary caries: } 2 \\
\text {-Tetric EvoCeram Bulk Fill: } \\
\text { Secondary caries: } 2 \\
\text {-SonicFill: } 0\end{array}$ & $\begin{array}{l}43 \\
43 \\
43\end{array}$ \\
\hline $7 a^{*}$ & $\begin{array}{l}\text { van Dijken e Pallesen, } \\
2014\end{array}$ & $\begin{array}{l}\text { - Ceram X mono }{ }^{+}: \\
\text {Tooth fracture: } 1 \text { Fracture of resin } \\
\text { composite: } 1\end{array}$ & 52 & - SDR + Ceram X mono ${ }^{+}: 0$ & 52 \\
\hline $8 a^{*}$ & $\begin{array}{l}\text { van Dijken e Pallesen, } \\
2015\end{array}$ & $\begin{array}{l}\text { - Ceram X mono }{ }^{+}: \\
\text {Tooth fracture: } 1\end{array}$ & 98 & $-\mathrm{SDR}+$ Ceram X mono ${ }^{+}: 0$ & 98 \\
\hline 9 & Alkurdi e Abboud, 2016 & $\begin{array}{l}\text { - Tetric Evo Ceram: } \\
\text { Discoloration marginal: } 1\end{array}$ & 20 & $\begin{array}{l}\text { - Tetric N Ceram Bulk Fill: } \\
\text { Discoloration marginal: } 2 \\
\text {-SonicFill: } 0\end{array}$ & 20 \\
\hline 3 & Çolak et al., 2017 & $\begin{array}{l}\text { - Tetric EvoCeram: } \\
\text { Marginal discoloration: } 1 \\
\end{array}$ & 35 & -Tetric EvoCeram Bulk Fill: 0 & 35 \\
\hline 4 & Atabek et al, 2017 & - Herculite: 0 & 30 & - SonicFill: 0 & 30 \\
\hline 5 & Yazici et al., 2017 & - Filtek Ultimate: 0 & 51 & - Tetric EvoCeram Bulk Fill: 0 & 51 \\
\hline \multirow[t]{2}{*}{6} & Oter et al., 2018 & - Filtek Z250: 0 & 50 & - Filtek Bulk-Fill Restorative: 0 & 50 \\
\hline & \multicolumn{5}{|c|}{18 months } \\
\hline \multirow[t]{2}{*}{5} & Yazici et al., 2017 & - Filtek Ultimate: 0 & 49 & - Tetric EvoCeram Bulk Fill: 0 & 49 \\
\hline & \multicolumn{5}{|c|}{24 months } \\
\hline 1 & Arhun et al., 2010 & - Grandio: Fracture of resin & 35 & - Quixfil: 0 & 35 \\
\hline
\end{tabular}


Research, Society and Development, v. 10, n. 10, e552101018981, 2021

(CC BY 4.0) | ISSN 2525-3409 | DOI: http://dx.doi.org/10.33448/rsd-v10i10.18981

\begin{tabular}{|c|c|c|c|c|c|}
\hline & & composite: 1 & & & \\
\hline 4 & Atabek et al, 2017 & - Herculite: 0 & 30 & - SonicFill: 0 & 30 \\
\hline 5 & Yazici et al., 2017 & - Filtek Ultimate: 0 & 42 & - Tetric EvoCeram Bulk Fill: 0 & 43 \\
\hline \multirow[t]{2}{*}{$8 a^{*}$} & $\begin{array}{l}\text { van Dijken e Pallesen, } \\
2015\end{array}$ & - Ceram X mono ${ }^{+}: 0$ & 98 & $\begin{array}{l}\text { - SDR + Ceram X mono }{ }^{+}: \\
\text {Tooth fracture: } 1 \\
\text { Caries and tooth fracture: } 1 \\
\text { Tooth fracture and resin composite fracture: } 1\end{array}$ & 98 \\
\hline & \multicolumn{5}{|c|}{36 months } \\
\hline 5 & Yazici et al., 2017 & - Filtek Ultimate: 0 & 40 & - Tetric EvoCeram Bulk Fill: 0 & 41 \\
\hline $7 \mathrm{a}^{*}$ & $\begin{array}{l}\text { van Dijken e Pallesen, } \\
2014\end{array}$ & $\begin{array}{l}- \text { Ceram } X \text { mono }^{+}: \\
\text {Fracture of resin composite: } 2\end{array}$ & 52 & $-\mathrm{SDR}+$ Ceram X mono ${ }^{+}: 0$ & 52 \\
\hline \multirow[t]{2}{*}{$8 a^{*}$} & $\begin{array}{l}\text { van Dijken e Pallesen, } \\
2015\end{array}$ & $\begin{array}{l}\text { - Ceram X mono }{ }^{+}: \\
\text {Tooth fracture: } 1 \text { Fracture of resin } \\
\text { composite: } 1\end{array}$ & 98 & $\begin{array}{l}\text { - SDR + Ceram X mono }{ }^{+}: \\
\text {Secondary caries: } 1\end{array}$ & 98 \\
\hline & \multicolumn{5}{|c|}{48 months } \\
\hline \multirow[t]{2}{*}{$8 \mathrm{~b}^{*}$} & $\begin{array}{l}\text { van Dijken e Pallesen, } \\
2016\end{array}$ & $\begin{array}{l}- \text { Ceram X mono }^{+}: \\
\text {Secondary caries: } 1\end{array}$ & 91 & - SDR + Ceram X mono ${ }^{+}: 0$ & 92 \\
\hline & \multicolumn{5}{|c|}{60 months } \\
\hline $8 \mathrm{~b}^{*}$ & $\begin{array}{l}\text { van Dijken e Pallesen, } \\
2016\end{array}$ & $\begin{array}{l}- \text { Ceram } X \text { mono }^{+}: \\
\text {Fracture of resin composite: } 1\end{array}$ & 91 & - SDR + Ceram X mono ${ }^{+}: 0$ & 92 \\
\hline \multirow[t]{2}{*}{$7 b^{*}$} & $\begin{array}{l}\text { van Djiken e Pallesen, } \\
2017\end{array}$ & $\begin{array}{l}\text { - Ceram } X \text { mono }{ }^{+} \text {: Fracture of } \\
\text { resin composite: } 1\end{array}$ & 49 & $\begin{array}{l}\text { - SDR + Ceram X mono }{ }^{+} \text {: Fracture of resin } \\
\text { composite: } 1\end{array}$ & 49 \\
\hline & \multicolumn{5}{|c|}{72 months } \\
\hline \multirow[t]{2}{*}{$7 b^{*}$} & $\begin{array}{l}\text { van Djiken e Pallesen, } \\
2017\end{array}$ & - Ceram X mono ${ }^{+}: 0$ & 49 & $\begin{array}{l}\text { - SDR + Ceram X mono }{ }^{+}: \text {Fracture of resin } \\
\text { composite: } 1 \\
\text { Secondary caries: } 1\end{array}$ & 49 \\
\hline & \multicolumn{5}{|c|}{ (2 } \\
\hline 10 & 10- Heck et al., 2018 & $\begin{array}{l}\text { - Tetric Ceram: } \\
\text { Secondary caries: } 2 \\
\text { Tooth fracture: } 1 \\
\text { Bulk fracture combined with } \\
\text { secondary caries: } 1\end{array}$ & 30 & $\begin{array}{l}\text { - Quixfil: } \\
\text { Secondary caries: } 1 \\
\text { Tooth fracture: } 2 \\
\text { Secondary caries combined with restoration fracture: } \\
1 \\
\text { Restoration fracture: } 1 \\
\text { Postoperative sensitivity: } 1 \\
\end{array}$ & 26 \\
\hline
\end{tabular}

* Search that generated more than one post. Source: Authors. 


\section{Evaluation of the study quality}

The quality of the studies is presented in Table 3. The value of the methodological quality scores of the studies ranged from $20-90 \%$, with an average score of $48.57 \%$. Only the study by Costa et al.(Costa et al., 2017) was classified with a high level of evidence. Eight studies were classified with a moderate level of evidence and five as a low level of evidence (Table 3).

With the studies quality data, it may be observed that two studies(Alkurdi \& Abboud, 2016; Atabek et al., 2017) did not present randomization method, being classified as a non-randomized clinical trial. Of the randomized trials, Yazici et al.(Yazici et al., 2017) study described the randomization method performed. In the masking question, no study received the maximum number of stars, and only the study by Hickey et al.(Hickey et al., 2016) did not receive any stars. Regarding the comparability of the groups, three studies(Alkurdi \& Abboud, 2016; Hickey et al., 2016; Yazici et al., 2017) did not report whether the groups were similar to each other, and three studies(Atabek et al., 2017; Çolak et al., 2017; Oter et al., 2018) were split-mouth. Only the study by Costa et al.(Costa et al., 2017) explained how the operator calibration method was performed to carry the treatments out. The calibration of the evaluators for the outcomes was performed in most studies, except only three(Alkurdi \& Abboud, 2016; Arhun et al., 2010; Hickey et al., 2016). The losses were reported by the studies, except for the study by Yazici et al.(Yazici et al., 2017). The losses in the follow-up were lower than $20 \%$ of the total sample (Table 3). 
Research, Society and Development, v. 10, n. 10, e552101018981, 2021

(CC BY 4.0) | ISSN 2525-3409 | DOI: http://dx.doi.org/10.33448/rsd-v10i10.18981

Table 3. Study quality evaluation.

\begin{tabular}{|c|c|c|c|c|c|c|c|c|}
\hline Study & Randomization & Masking & Comparability & Intervention & Outcome & Looses & Maximum $10^{*}$ & Maximum $100 \%$ \\
\hline Arhun et al., 2010 & $*$ & $* *$ & $*$ & No & No & $*$ & $5 / 10$ & $50 \%$ \\
\hline van Dijken e Pallesen, 2014 & $*$ & $* *$ & $*$ & $\mathrm{No}^{\Delta}$ & $*$ & $*$ & $6 / 10$ & $60 \%$ \\
\hline van Dijken e Pallesen, 2015 & $*$ & $* *$ & $*$ & $\mathrm{No}^{\Delta}$ & $*$ & $*$ & $6 / 10$ & $60 \%$ \\
\hline Bayraktar et al., 2016 & $*$ & $* *$ & $*$ & $\mathrm{No}^{\Delta}$ & $*$ & $*$ & $6 / 10$ & $60 \%$ \\
\hline Alkurdi e Abboud, 2016 & No & $*$ & No & No & No & $*$ & $2 / 10$ & $20 \%$ \\
\hline Hickey et al., 2016 & * & No & No & No & No & $*$ & $2 / 10$ & $20 \%$ \\
\hline van Dijken e Pallesen, 2016 & $*$ & $* *$ & $*$ & $\mathrm{No}^{\Delta}$ & $*$ & $*$ & $6 / 10$ & $60 \%$ \\
\hline Costa et al., 2017 & $* * *$ & $* *$ & $*$ & $*$ & $*$ & $*$ & $9 / 10$ & $90 \%$ \\
\hline Çolak et al., 2017 & $*$ & $* *$ & Split-mouth & No & $*$ & $*$ & $5 / 10$ & $50 \%$ \\
\hline Atabek et al., 2017 & No & $*$ & Split-mouth & $\mathrm{No}^{\Delta}$ & $*$ & $*$ & $3 / 10$ & $30 \%$ \\
\hline van Djiken e Pallesen, 2017 & $*$ & $* *$ & $*$ & $\mathrm{No}^{\Delta}$ & $*$ & $*$ & $6 / 10$ & $60 \%$ \\
\hline Yazici et al., 2017 & $*$ & $*$ & No & No & $*$ & No & $3 / 10$ & $30 \%$ \\
\hline Oter et al., 2018 & $*$ & *** & Split-mouth* & $*$ & $*$ & $*$ & $7 / 10$ & $70 \%$ \\
\hline Heck et al., 2018 & * & No & Split-mouth & $\mathrm{No}^{\Delta}$ & No & * & $2 / 10$ & $20 \%$ \\
\hline
\end{tabular}

${ }^{\Delta}$ Operator was not calibrated, however, was a professional with experience in Restorative Dentistic. Source: Authors. 
Research, Society and Development, v. 10, n. 10, e552101018981, 2021

(CC BY 4.0) | ISSN 2525-3409 | DOI: http://dx.doi.org/10.33448/rsd-v10i10.18981

\section{Meta-analysis}

The meta-analysis included only 11 studies selected in the systematic review. The failure rates of bulk-fill and conventional resin composite restorations were evaluated using subgroups according to the follow-up times. No significant differences were observed between conventional resin composites and bulk-fill for each follow-up time, for each type of failure (Fig. 2-5).

Figure 2. Forest plots of included studies: A. Forest plot of discoloration marginal at 6 months; B Forest plot of discoloration marginal at 12 months.

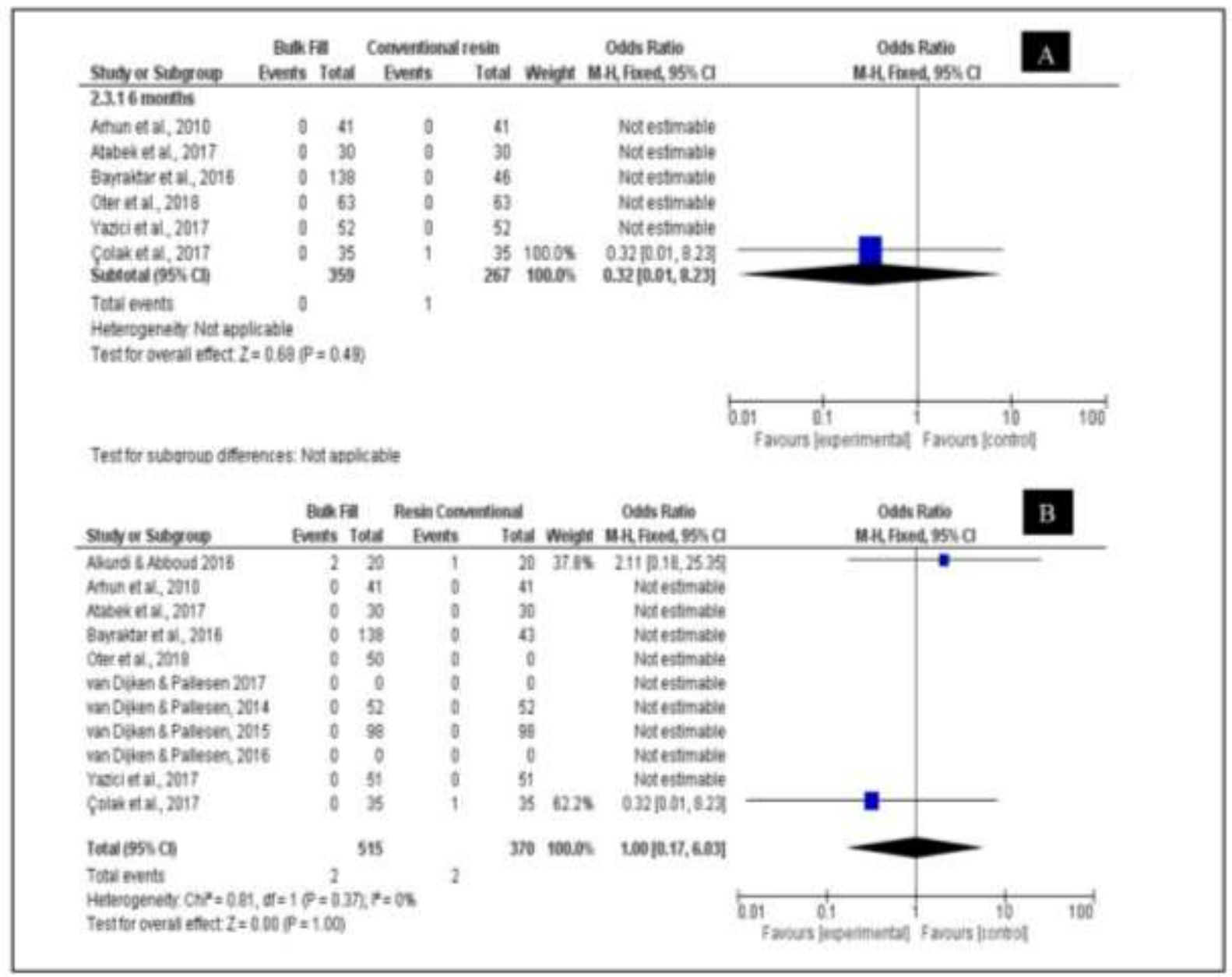

Source: Authors.

Another type of failure assessed in the meta-analysis was fractures that were classified into the material fracture and tooth fracture, being followed up during the period of 12(Alkurdi \& Abboud, 2016; Arhun et al., 2010; Atabek et al., 2017; Bayraktar et al., 2017; Çolak et al., 2017; Oter et al., 2018; van Dijken \& Pallesen, 2014, 2015, 2016, 2017; Yazici et al., 2017) 24(Alkurdi \& Abboud, 2016; Arhun et al., 2010; Atabek et al., 2017; Bayraktar et al., 2017; Çolak et al., 2017; Oter et al., 2018; van Dijken \& Pallesen, 2014, 2015, 2016, 2017; Yazici et al., 2017) and 36 months(van Dijken \& Pallesen, 2014, 2015; Yazici et al., 2017). For all the evaluation periods and fracture types, there was no significant difference between the materials tested (Figure 3-4). 
Research, Society and Development, v. 10, n. 10, e552101018981, 2021

(CC BY 4.0) | ISSN 2525-3409 | DOI: http://dx.doi.org/10.33448/rsd-v10i10.18981

Figure 3. Forest plots of included studies: A. Forest plot of fracture of material at 12 months; B. Forest plot of fracture of material at 24 months; C. Forest plot of fracture of material at 36 months.

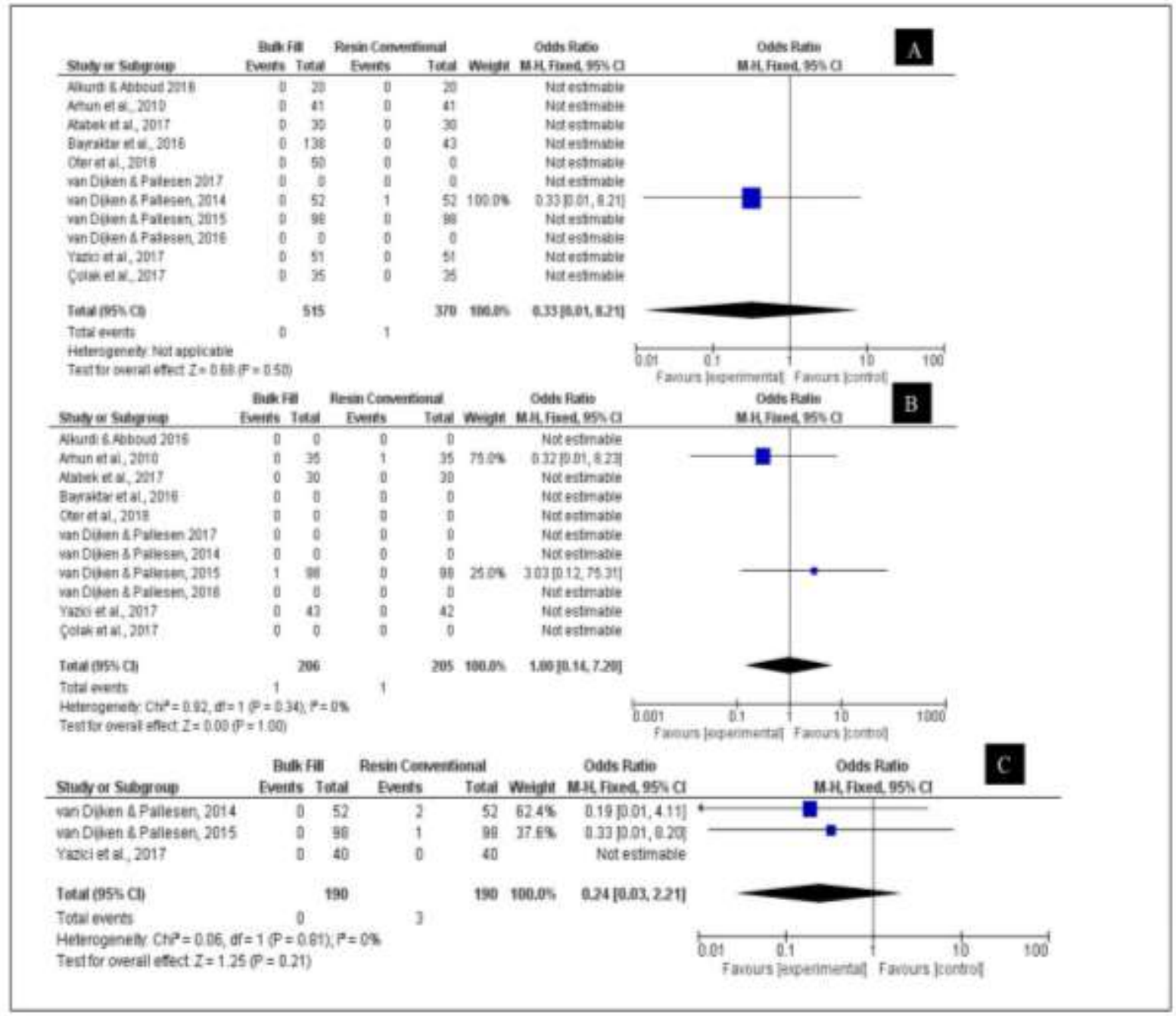

Source: Authors. 
Research, Society and Development, v. 10, n. 10, e552101018981, 2021

(CC BY 4.0) | ISSN 2525-3409 | DOI: http://dx.doi.org/10.33448/rsd-v10i10.18981

Figure 4. Forest plots of included studies: A. Forest plot of tooth fracture at 12 months; B. Forest plot of tooth fracture at 24 months; C. Forest plot of tooth fracture at 36 months.

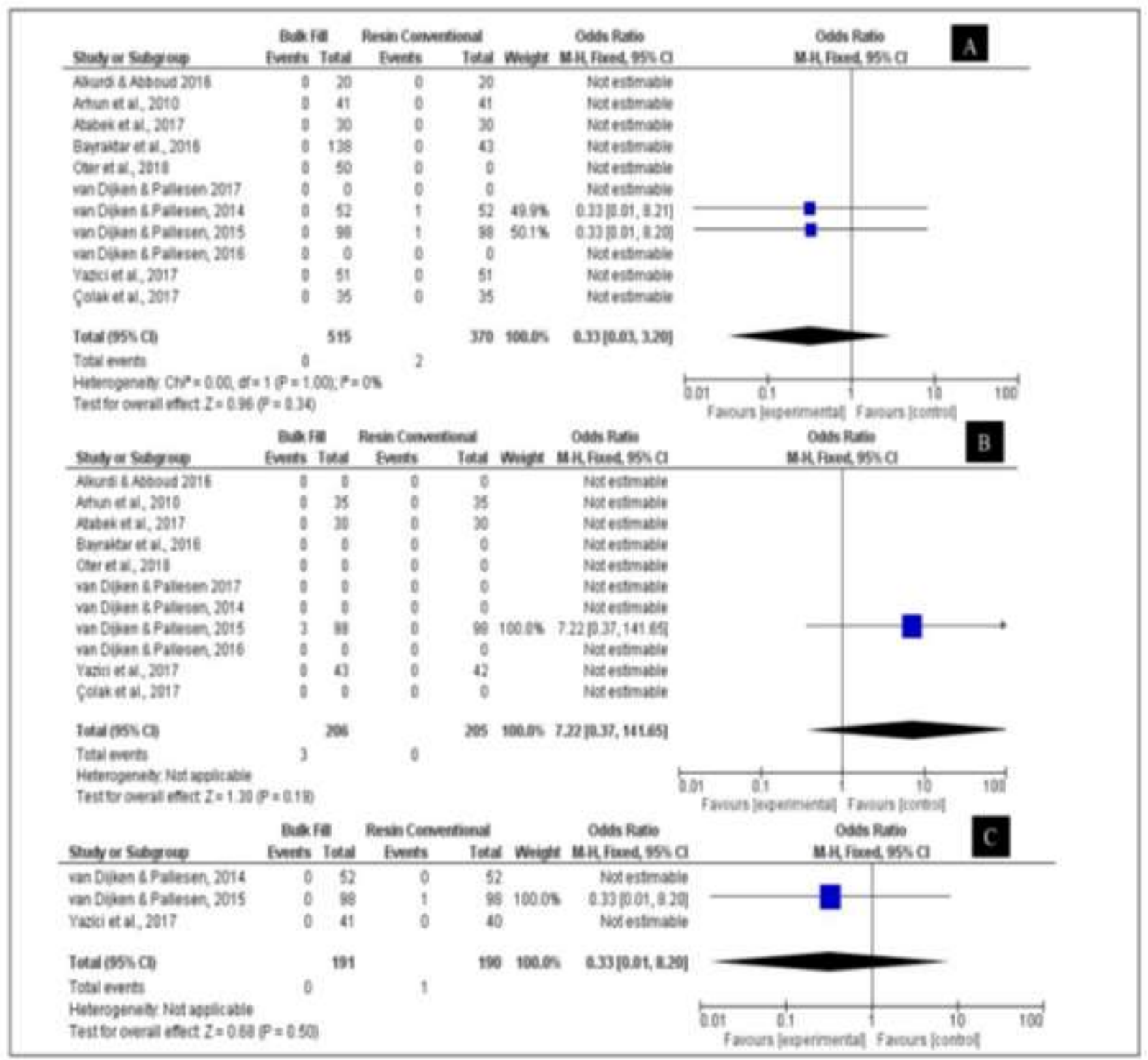

Source: Authors. 
Figure 5. Forest plots of included studies: A. Forest plot of secondary caries at 12 months; B. Forest plot of secondary caries at 36 months.

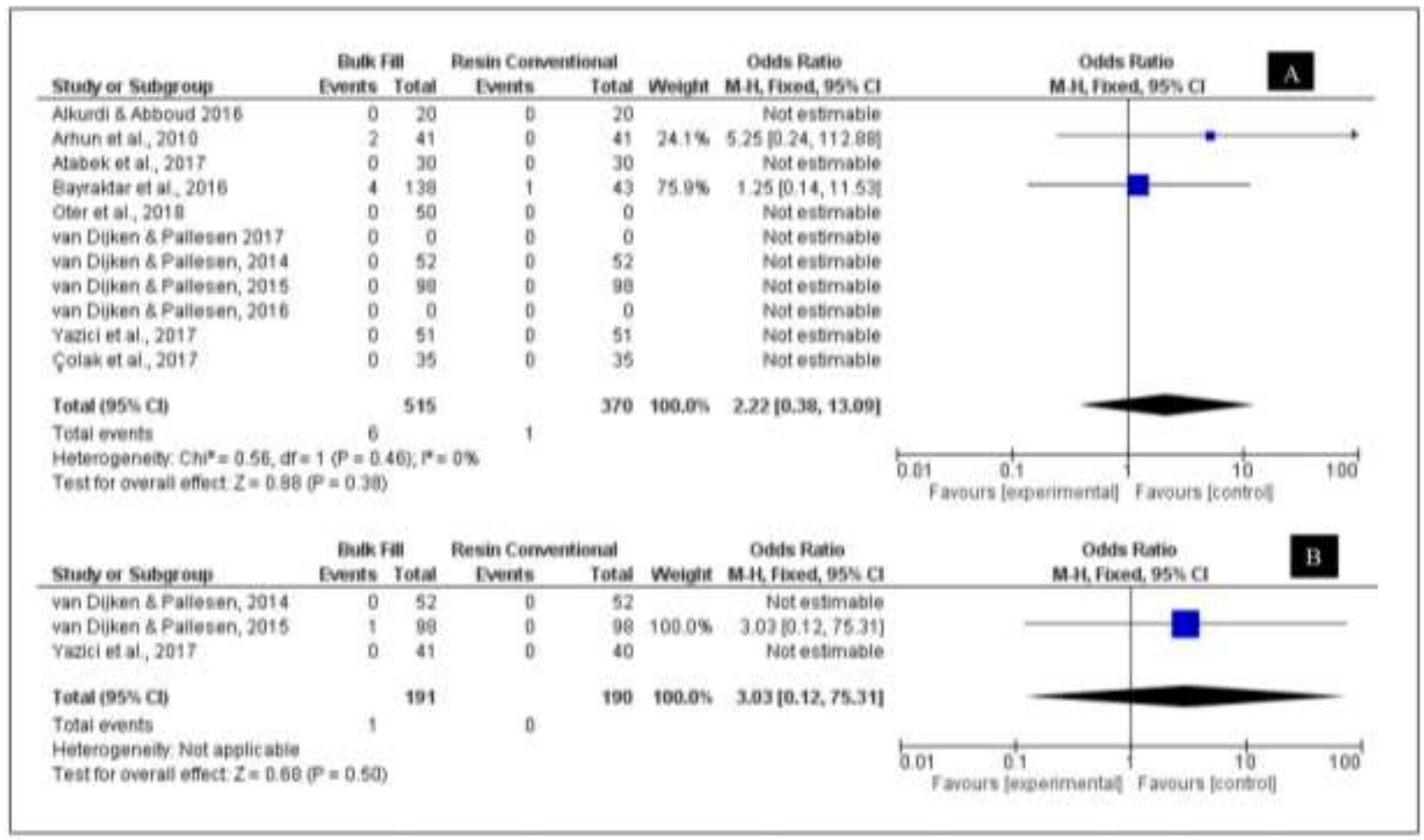

Source: Authors.

\section{Discussion}

With the increasing acceptance of the clinical use of bulk-fill resins, it is necessary to investigate the in vivo performance of these restorative materials. In this perspective, this systematic review indicates that the composite resins; conventional (incremental technique) and bulk-fill (increment up to 5mm), presented in short and medium-term, a satisfactory clinical performance in primary and permanent posterior teeth. Most of the clinical outcomes evaluated in the different studies were similar for the two types of resin used.

The systematic review and meta-analysis performed by Veloso et al., 2018 (Veloso et al., 2018) demonstrated the clinical failure rate in direct restorations with bulk-fill and conventional restorations using subgroups that divided the bulk-fill resins into: base/flowable and full-body/sculptable within a follow-up period of 12 to 72 months. No difference was found between conventional resin composites and bulk-fill resin composites. The systematic review and meta-analysis by Boaro et al., 2019(Cidreira Boaro et al., 2019) reinforces the good chemical-physical properties of bulk fill when compared to conventional composites resin, and the clinical aspect regarding the type of bulk-fill resin (base/flowable and full-body /sculptable) are also analyzed in other studies (Cidreira Boaro et al., 2019; Veloso et al., 2018). Meanwhile, in the present meta-analysis, the failure rate was evaluated according to the study follow-up time (treatment longevity $\mathrm{x}$ clinical features), showing no difference between conventional resin and bulk-fill resin when evaluated for a period of up to 10 years of followup.

The selection of quality clinical studies, that is, with a low occurrence of bias (Hickel et al., 2007; Schulz et al., 2011) gives validity to the findings. However, for this systematic review, no clinical study was free of potential biases. In the clinical trials analyzed, were observed failures in the randomization (Alkurdi \& Abboud, 2016; Atabek et al., 2017), masking(Hickey 
Research, Society and Development, v. 10, n. 10, e552101018981, 2021

(CC BY 4.0) | ISSN 2525-3409 | DOI: http://dx.doi.org/10.33448/rsd-v10i10.18981

et al., 2016) and calibration(Bayraktar et al., 2017; van Dijken \& Pallesen, 2014, 2015, 2016, 2017) that as reposted in the literature (Ástvaldsdóttir et al., 2015) may compromise the interpretation of findings that should be carefully analyzed.

The clinical longevity of composite resin restorations was analyzed in the study through outcomes such as: postoperative sensitivity, marginal discoloration/adaptation, secondary caries, anatomical form, texture and surface roughness. Most of the studies (87,5\%) (Alkurdi \& Abboud, 2016; Bayraktar et al., 2017; Oter et al., 2018; van Dijken \& Pallesen, 2014, 2015, 2016, 2017; Yazici et al., 2017) clinically evaluated the restorations by the modified USPHS method, which is a widely used instrument (Hickel et al., 2010) and congregate all the outcomes previously mentioned. However, in the study by Hickey et al. (Hickey et al., 2016), the LIKERT scale was used, which is a validated scale used to verify the outcome of the dental sensitivity and masticatory discomfort (Hickey et al., 2016).

The postoperative sensitivity outcome may be influenced by factors, such as: the previous condition of the teeth regarding the extension and depth of the cavities(Hickey et al., 2016), the formation of gaps(Reis et al., 2015), the polymerization stress and shrinkage(Braga et al., 2005; Kwon et al., 2012), the types of materials and techniques(van Dijken \& Pallesen, 2014), among other factors(Fosse et al., 1992; Han \& Park, 2017) Regardless of the material used the postoperative sensitivity was reported in 62.5\% of the studies(Alkurdi \& Abboud, 2016; Bayraktar et al., 2017; Hickey et al., 2016; van Dijken \& Pallesen, 2014; Yazici et al., 2017). Hickey et al.(Hickey et al., 2016) observed a postoperative sensitivity was observed in the teeth restored with bulk-fill resin and conventional resin, although two days after the procedure, the teeth restored with bulk-fill presented a significant increase in the degree of postoperative sensitivity when compared to the conventional resin. However, after the 7th day, this difference was not significant(Hickey et al., 2016). It is suggested that the postoperative sensitivity has been influenced by the previous existence of carious lesions and depth/extension of the cavity preparation since there was no standardization or depth measurement of the same.

A severe postoperative sensitivity was verified by Alkurdi and Abboud(Alkurdi \& Abboud, 2016) in two cases of class II restorations with bulk-fill resin (Tetric N-Ceram Bulk-fill) in premolars, requiring the replacement of the restorations and performing the endodontic treatment. It is worth mentioning that the premolar teeth present more evident pulp horns, with less dentin on the pulp chamber when compared to the permanent molars(Alkurdi \& Abboud, 2016), and carious lesions in deep dentin cover an area with a greater number of tubules and with a greater diameter(Fosse et al., 1992). In deep cavities, lower monomer conversion rates and monomer extravasation into the pulp tissue may also cause dental sensitivity and progress to irreversible pulp irritation(Alkurdi \& Abboud, 2016). The Bis-GMA monomer is considered very viscous and less flexible due to the strong intramolecular hydrogen bonding through its hydroxyl-OH groups and the presence of rigid aromatic nuclei in its structure(Khatri et al., 2003). This implies a low reactivity and final conversion degree of this material(Alshali et al., 2013; Sideridou et al., 2002). Once the Tetric N-Ceram Bulk-fill resin presents a high concentration of Bis-GMA in its composition, such fact may explain the occurrence of greater postoperative sensitivity reported in the study by Alkurdi and Abboud(Alkurdi \& Abboud, 2016). However, in this systematic review, according to the results found, 75\% of studies(Bayraktar et al., 2017; van Dijken \& Pallesen, 2014, 2015, 2016, 2017; Yazici et al., 2017) reported that there's no significant difference between the type of resin used and the occurrence of postoperative sensitivity, while $25 \%$ of the studies found a significant difference(Alkurdi \& Abboud, 2016; Hickey et al., 2016). Restorations in primary teeth were verified only in the study of Oter et al.(Oter et al., 2018), in which they observed a higher occurrence of postoperative sensitivity in the teeth restored with bulk-fill. But there was no statistically significant difference between these two materials $(\mathrm{P}>0.05)$, during 6-12 months for postoperative sensitivity(Oter et al., 2018).

The marginal discoloration/adaptation and secondary caries are clinical outcomes that occur more in the interproximal areas, by being the most challenging regions(van Dijken \& Pallesen, 2015). While there are studies(Alkurdi \& 
Research, Society and Development, v. 10, n. 10, e552101018981, 2021

(CC BY 4.0) | ISSN 2525-3409 | DOI: http://dx.doi.org/10.33448/rsd-v10i10.18981

Abboud, 2016; Bayraktar et al., 2017) that found no influence of materials on discoloration and marginal adaptation of restorations. Yazici et al.(Yazici et al., 2017), verified better clinical results for the bulk-fill restoration (Tetric EvoCeram Bulk-fill). It has been observed that the volume of shrinkage polymerization is similar in bulk-fill and conventional resins and that this shrinkage has a positive correlation with the formation of gaps(Almeida Junior et al., 2017). The occurrence of small defects or the formation of gaps allows the passage of cariogenic bacteria and/or retention of pigments that may generate color change in the margin of the restoration (14). However, the presence of gaps at the margins of the restorations does not always appear to be related to the development of caries(Kidd \& Beighton, 1996). This relationship only seems to have a significant effect when the marginal gap has a width compatible with the thickness of the active tip of the periodontal probe (400 $\mu \mathrm{m})($ Heintze et al., 2009). However, the longevity of the restorations may be compromised, when the replacement of the restoration is premature, generating an overtreatment due to the misdiagnosis of secondary caries(Sarrett DC, 2007).

Secondary caries was verified in $37.5 \%$ of the restorations(Bayraktar et al., 2017; van Dijken \& Pallesen, 2016, 2017), after 1 to 5 years of follow-up, regardless of the type of the material used. Recurrences of lesions and caries evolve mainly in the proximal surfaces(Mjor IA, 1998; Oter et al., 2018; van Dijken \& Pallesen, 2016), and this systematic review had demonstrated that the restorations failure rate were more prevalent in proximal (class II) than in the occlusal (class I) of the teeth(van Dijken \& Pallesen, 2014, 2015, 2016, 2017). In proximal restorations factors such as: the absence of enamel on the gingival wall and subgingival endings may compromise the adhesion of resinous materials (Poggio et al., 2013). Besides, inadequate sealing of the margins may allow the penetration of fluids, bacteria, and debris into the cavity(Marí et al., 2019). Also, the difficulty of sanitizing areas near the gingival wall makes small marginal interface defects to be associated with the development of secondary caries(Mjor IA, 1998).

The anatomical form, texture and surface roughness of the restorations are factors that are directly related among them. However, the lack of standardization of the performed restorations makes it difficult to compare the studies. For the restoration of posterior teeth, the bulk-fill resin is being used alone in a single increment(Alkurdi \& Abboud, 2016; Bayraktar et al., 2017; Yazici et al., 2017) or associated with the last layer in a conventional composite resin(Bayraktar et al., 2017; van Dijken \& Pallesen, 2014, 2015, 2016, 2017). A significant change over time in the color of the conventional resins restoration was observed, which could be explained by a change in surface texture, despite this aspect presented satisfactory over time(van Dijken \& Pallesen, 2014, 2017). In the studies that were used the single-increment bulk-fill resins, similar color stability was observed to restorations with conventional resins(Alkurdi \& Abboud, 2016; Bayraktar et al., 2017; Yazici et al., 2017).

The limitations of this review is that few clinical studies with longer follow-up time was conducted to evaluate the behavior of bulk-fill resins because so far, most studies have less than 5 years of evaluation. In the short term, clinical studies point out a satisfactory behavior of bulk-fill resins.

\section{Conclusion}

From this systematic review, it may be concluded that the lack of standardization of the studies makes it difficult to compare the materials, however in the short term, the restorations in primary and permanent teeth with bulk-fill resins present satisfactory clinical performance when evaluating outcomes such as postoperative sensitivity, secondary caries, marginal adaptation, anatomical form, color matching, texture and surface roughness.

Besides that the failures occurrence that compromises the longevity of the restorations in primary and permanent teeth may be more associated with the inherent characteristics of the cavity preparation and location of the lesions, than to the type of resin and the technique used. 
Research, Society and Development, v. 10, n. 10, e552101018981, 2021 (CC BY 4.0) | ISSN 2525-3409 | DOI: http://dx.doi.org/10.33448/rsd-v10i10.18981

\section{Acknowledgments}

Coordination for the Improvement of Higher Education Personnel - Brazil (CAPES) - Finance Code 001". Foundation for the Support of Research and Scientific and Technological Development of Maranhão - Brazil (FAPEMA)

\section{References}

Al Sunbul, H., Silikas, N., \& Watts, D. (2016). Polymerization shrinkage kinetics and shrinkage-stress in dental resin-composites. Dental Materials, 32(8), 998-1006. https://doi.org/10.1016/j.dental.2016.05.006

Alkurdi, R., \& Abboud, S. (2016). Clinical evaluation of class II composite: Resin restorations placed by two different bulk-fill techniques. Journal of Orofacial Sciences, 8, 34-39. https://doi.org/10.4103/0975-8844.181926

Almeida Junior, L., Penha, K., Souza, A., Lula, E., Magalhães, F., Lima, D., \& Firoozmand, L. (2017). Is there correlation between polymerization shrinkage, gap formation, and void in bulk fill composites? A $\mu$ CT study. Brazilian Oral Research, 31(0), 1-10. https://doi.org/10.1590/1807-3107bor-2017.vol31.0100

Alshali, R., Silikas, N., \& Satterthwaite, J. (2013). Degree of conversion of bulk-fill compared to conventional resin-composites at two time intervals. Dental Materials, 29(9), e213-e217. https://doi.org/10.1016/j.dental.2013.05.011

Arhun, N., Celik, C., \& Yamanel, K. (2010). Clinical Evaluation of Resin-based Composites in Posterior Restorations: Two-year Results. Operative Dentistry, 35(4), 397-404. https://doi.org/10.2341/09-345-c

Ástvaldsdóttir, Á., Dagerhamn, J., van Dijken, J., Naimi-Akbar, A., Sandborgh-Englund, G., Tranæus, S., \& Nilsson, M. (2015). Longevity of posterior resin composite restorations in adults - A systematic review. Journal of Dentistry, 43(8), 934-954. https://doi.org/10.1016/j.jdent.2015.05.001

Atabek, D., Aktas, N., Sakaryali, D., \& Bani, M. (2017). Two-year clinical performance of sonic-resin placement system in posterior restorations. Quintessence International, 48(9), 743-751. https://doi.org/10.3290/j.qi.a38855

Bayraktar, Y., Ercan, E., Hamidi, M. M., \& Çolak, H. (2017). One-year clinical evaluation of different types of bulk-fill composites. Journal of Investigative and Clinical Dentistry, 8(2), 1-9. https://doi.org/10.1111/jicd.12210

Braga, R., Ballester, R., \& Ferracane, J. (2005). Factors involved in the development of polymerization shrinkage stress in resin-composites: A systematic review. Dental Materials, 21(10), 962-970.

Casagrande, L., Dalpian, D. M., Ardenghi, T. M., Zanatta, F. B., Balbinot, C. E. A., García-Godoy, F., \& De Araujo, F. B. (2013). Randomized clinical trial of adhesive restorations in primary molars. 18-month results. American Journal of Dentistry, 26(6), 351-355.

Cidreira Boaro, L., Pereira Lopes, D., de Souza, A., Lie Nakano, E., Ayala Perez, M., Pfeifer, C., \& Gonçalves, F. (2019). Clinical performance and chemicalphysical properties of bulk fill composites resin — a systematic review and meta-analysis. Dental Materials, 19(S0109-5641), 30683-30689. https://doi.org/10.1016/j.dental.2019.07.007

Çolak, H., Tokay, U., Uzgur, R., Hamidi, M., \& Ercan, E. (2017). A prospective, randomized, double-blind clinical trial of one nano-hybrid and one highviscosity bulk-fill composite restorative systems in class II cavities: 12 months results. Nigerian Journal of Clinical Practice, 20(7), 822-831. https://doi.org/10.4103/1119-3077.212449

Costa, T., Rezende, M., Sakamoto, A., Bittencourt, B., Dalzochio, P., Loguercio, A., \& Reis, A. (2017). Influence of adhesive type and placement technique on postoperative sensitivity in posterior composite restorations. Operative Dentistry, 42(2), 143-154. https://doi.org/10.2341/16-010-C

Czasch, P., \& Ilie, N. (2013). In vitro comparison of mechanical properties and degree of cure of bulk fill composites. Clinical Oral Investigations, 17(1), 227-235. https://doi.org/10.1007/s00784-012-0702-8

Dennison, J., \& Sarrett, D. (2012). Prediction and diagnosis of clinical outcomes affecting restoration margins. Journal of Oral Rehabilitation, 39(4), 301-318. https://doi.org/10.1111/j.1365-2842.2011.02267.x

Ferracane, J., \& Hilton, T. (2016). Polymerization stress - Is it clinically meaningful? Dental Materials, 32(1), 1-10. https://doi.org/10.1016/j.dental.2015.06.020

Fosse, G., Saele, P., \& Eide, R. (1992). Numerical density and distributional pattern of dentin tubules. Acta Odontologica Scandinavica, 50(4), 201-210.

Fronza, B., Rueggeberg, F., Braga, R., Mogilevych, B., Soares, L., Martins, A., Ambrosano, G., \& Giannini, M. (2015). Monomer conversion, microhardness, internal marginal adaptation, and shrinkage stress of bulk-fill resin composites. Dental Materials, 31(12), 1542-1551. https://doi.org/10.1016/j.dental.2015.10.001

Gonçalves, F., Pfeifer, C., Ferracane, J., \& Braga, R. (2008). Contraction Stress Determinants in Dimethacrylate Composites. J Dent Res, 87(4), 367-371.

Han, S., \& Park, S. (2017). Comparison of Internal Adaptation in Class II Bulk-fill Composite Restorations Using Micro-CT. Operative Dentistry, 42(2), 203214.

Heintze, S., Blunck, U., Göhring, T., \& Rousson, V. (2009). Marginal adaptation in vitro and clinical outcome of Class V restorations. Dental Materials, 
Research, Society and Development, v. 10, n. 10, e552101018981, 2021 (CC BY 4.0) | ISSN 2525-3409 | DOI: http://dx.doi.org/10.33448/rsd-v10i10.18981

25(5), 605-620. https://doi.org/10.1016/j.dental.2008.11.004

Heintze, S., Rousson, V., \& Mahn, E. (2015). Bond strength tests of dental adhesive systems and their correlation with clinical results - A meta-analysis. Dental Materials, 31(4), 423-434. https://doi.org/10.1016/j.dental.2015.01.011

Hickel, R., Peschke, A., Tyas, M., Mjör, I., Bayne, S., Peters, M., Hiller, K., Randall, R., Vanherle, G., \& Heintze, S. (2010). FDI World Dental Federation: Clinical criteria for the evaluation of direct and indirect restorations-update and clinical examples. Clinical Oral Investigations, 14(4), 349-366. https://doi.org/10.1007/s00784-010-0432-8

Hickel, R., Roulet, J., Bayne, S., Heintze, S., Mjör, I., Peters, M., \& Et, A. (2007). Recommendations for conducting controlled clinical studies of dental restorative materials. Clin Oral Investig, 5-33.

Hickey, D., Sharif, O., Janjua, F., \& Brunton, P. A. (2016). Bulk dentine replacement versus incrementally placed resin composite: A randomised controlled clinical trial. Journal of Dentistry, 46, 18-22. https://doi.org/10.1016/j.jdent.2016.01.011

Higgins, J., Altman, D., Gøtzsche, P., Jüni, P., Moher, D., Oxman, A., Savović, J., Schulz, K., Weeks, L., \& Sterne, J. (2011). The Cochrane Collaboration’s tool for assessing risk of bias in randomised trials. BMJ (Online), 343, 1-9. https://doi.org/10.1136/bmj.d5928

Karaman, E., Keskin, B., \& Inan, U. (2016). Three-year clinical evaluation of class II posterior composite restorations placed with different techniques and flowable composite linings in endodontically treated teeth. Clinical Oral Investigations, 21(2), 709-716. https://doi.org/10.1007/s00784-016-1940-y

Khatri, C., Stansbury, J., Schultheisz, C., \& Antonucci, J. (2003). Synthesis, characterization and evaluation of urethane derivatives of Bis-GMA. Dental Materials, 19(7), 584-588.

Kidd, E., \& Beighton, D. (1996). Prediction of secondary caries around tooth-colored restorations: a clinical and microbiological study. J Dent Res, 75, 19421946.

Kurdi, R., \& Abboud, S. (2016). Clinical evaluation of class II composite resin restorations using two different bulk-fill techniques. International Arab Journal of Dentistry, 7(2).

Kwon, Y., Ferracane, J., \& Lee, I. (2012). Effect of layering methods, composite type, and flowable liner on the polymerization shrinkage stress of light cured composites. Dental Materials, 28(7), 801-809.

Marí, L., Gil, A., \& Puy, C. (2019). In vitro evaluation of microleakage in Class II composite restorations : High- viscosity bulk-fill vs conventional composites. Dental Materials Journal, 38(5), 721-727. https://doi.org/10.4012/dmj.2018-160

Mjor IA. (1998). The location of clinically diagnosed secondary caries. Quintessence Int, 29, 313-317.

Moher, D., Liberati, A., Tetzlaff, J., Altman, D., \& PRISMA Group. (2009). Preferred reporting items for systematic reviews and meta-analyses: The PRISMA statement. PLoS Med, 6(7). https://doi.org/10.3736/jcim20090918

Olegário, I., Hesse, D., Bonecker, M., Imparato, J., Braga, M., Mendes, F., \& Raggio, D. (2017). Effectiveness of conventional treatment using bulk-fill composite resin versus Atraumatic Restorative Treatments in primary and permanent dentition: a pragmatic randomized clinical trial. BMC Oral Health, 17(34), 1-8. https://doi.org/10.1186/s12903-016-0260-6

Orlowski, M., Tarczydło, B., \& Chałas, R. (2015). Evaluation of marginal integrity of four bulk-fill dental composite materials: In vitro study. The Scientific World Journal. https://doi.org/10.1155/2015/701262

Oter, B., Deniz, K., \& Çehreli, S. (2018). Preliminary data on clinical performance of bulk-fill restorations in primary molars. Nigerian Journal of Clinical Practice, 21(11), 1484-1491. https://doi.org/10.4103/njcp.njcp_151_18

Poggio, C., Chiesa, M., Scribante, A., Mekler, J., \& Colombo, M. (2013). Microleakage in Class II composite restorations with margins below the CEJ : In vitro evaluation of different restorative techniques. Med Oral Patol Oral Cir Bucal, 18(5), 793-798. https://doi.org/10.4317/medoral.18344

Reis, A., Loguercio, A., Schroeder, M., Luque-Martinez, I., Masterson, D., \& Maia, L. (2015). Does the adhesive strategy influence the post-operative sensitivity in adult patients with posterior resin composite restorations?: A systematic review and meta-analysis. Dental Materials, 31(9), 1052-1067. https://doi.org/10.1016/j.dental.2015.06.001

Roggendorf, M., Kramer, N., Appelt, A., Naumann, M., \& Frankenberger, R. (2011). Marginal quality of flowable 4-mm base vs . conventionally layered resin composite. Journal of Dentistry, 39(10), 643-647. https://doi.org/10.1016/j.jdent.2011.07.004

Sarrett DC. (2007). Prediction of clinical outcomes of a restoration based on in vivo marginal quality evaluation. J Adhes Dent, 9(1), 117-120.

Schneider, L., Cavalcante, L., \& Silikas, N. (2010). Shrinkage stresses generated during resin-composite applications: A review. Journal of Dental Biomechanics, 1-14. https://doi.org/10.4061/2010/131630

Schulz, K., Altman, D., \& Moher, D. (2011). CONSORT 2010 Statement: Updated guidelines for reporting parallel group randomized trials. International Journal of Surgery, 9, 672-677. https://doi.org/10.1136/bmj.c332

Sideridou, I., Tserki, V., \& Papanastasiou, G. (2002). Effect of chemical structure on degree of conversion in light-cured dimethacrylate-based dental resins. Biomaterials, 23(8), 1819-1829.

Stansbury, J., Trujillo-Lemon, M., Lu, H., Ding, X., Lin, Y., \& Ge, J. (2005). Conversion-dependent shrinkage stress and strain in dental resins and composites. Dental Materials, 21(1), 56-67. https://doi.org/10.1016/j.dental.2004.10.006 
Research, Society and Development, v. 10, n. 10, e552101018981, 2021 (CC BY 4.0) | ISSN 2525-3409 | DOI: http://dx.doi.org/10.33448/rsd-v10i10.18981

van Dijken, J. W. V., \& Pallesen, U. (2014). A randomized controlled three year evaluation of bulk-filled posterior resin restorations based on stress decreasing resin technology. Dental Materials, 30(9), e245-e251. https://doi.org/10.1016/j.dental.2014.05.028

van Dijken, J. W. V., \& Pallesen, U. (2015). Randomized 3-year clinical evaluation of class I and II posterior resin restorations placed with a bulk-fill resin composite and a one-step self-etching adhesive. Journal of Adhesive Dentistry, 17(1), 81-88. https://doi.org/10.3290/j.jad.a33502

van Dijken, J. W. V., \& Pallesen, U. (2016). Posterior bulk-filled resin composite restorations: A 5-year randomized controlled clinical study. Journal of Dentistry, 51, 29-35. https://doi.org/10.1016/j.jdent.2016.05.008

van Dijken, J. W. V., \& Pallesen, U. (2017). Bulk-filled posterior resin restorations based on stress-decreasing resin technology: a randomized, controlled 6year evaluation. European Journal of Oral Sciences, 125(4), 303-309. https://doi.org/10.1111/eos.12351

Veloso, S., Lemos, C., de Moraes, S., do Egito Vasconcelos, B., EP, P., \& de Melo Monteiro, G. (2018). Clinical performance of bulk-fill and conventional resin composite restorations in posterior teeth: a systematic review and meta-analysis. Clinical Oral Investigations, 23(1), 221-233. https://doi.org/10.1007/s00784-018-2429-7

Yazici, A., Antonson, S., Kutuk, Z., \& Ergin, E. (2017). Thirty-Six-Month Clinical Comparison of Bulk Fill and Nanofill Composite Restorations. Operative Dentistry, 42(5), 478-485. https://doi.org/10.2341/16-220-c 